any empirical evidence. Moreover, he has not even shied away from letting his views be known about such clinical matters as ECT, a view which is inevitably ideological as he is neither a clinician nor a scientist.

It is interesting that Dr Peet mentions 'deskilling' as one of the ways psychiatrists might deal with their role in community multidisciplinary teams. I had not heard this term in this context until my visit to the above district but during the course of one day I found it had become an established part of my vocabulary.

The new management structure seems to have provided a vehicle that can be used by certain managers who happen to hold strong views on mental health to promote antipsychiatry views and to encourage the 'deskilling' of psychiatrists. I think that this could represent a serious challenge to psychiatry and, judging by recent newspaper articles, psychiatrists' views do not seem to be much in evidence.

\section{Fulbourn Hospital \\ Cambridge}

RiAdH T. ABED

\section{Dr Vidya Sagar Kaushalya Devi Memorial Trust}

Dear Sirs

Dr Vidya Sagar was an eminent Indian psychiatrist, who trained at the Institute of Psychiatry, London, (1948-51) and dedicated his whole life to the care and attention of the mentally ill. He worked at first at the Mental Hospital, Amritsar and later on at Medical College, Rohtak.

His family, friends, relatives, colleagues and students have set up a charitable trust: Dr Vidya Sagar Kaushalya Devi Memorial Trust. The aims of the trust are to set up a Health Centre dedicated to carry out his ideals. The trust has received moral and physical support from a wide spectrum. The government of India has given four acres of valuable land in the centre of New Delhi. The Delhi corporation has promised financial support towards construction work. The Health Centre has the possibility of being a premier centre for psychiatric education and research.

Indian psychiatry has enjoyed a close and cordial relationship with its British counterpart. Most Indian psychiatrists have worked and trained in this country or North America. Teaching and training programmes at various academic centres in India have received extensive help and guidance from academic organisations in the United Kingdom, in particular the Institute of Psychiatry. We hope that with the Vidya Sargar Health Centre we will receive similar support not only from psychiatrists of Indian origin working outside India, but also from friends and well wishers all over the world. This is a worthy cause which requires urgent support. Financial donations should be made out to Vidya Sargar and crossed Account Payee Only. Offers of any other form of help should be conveyed to one of us (RG).

112 A Harley Street,

RAGHU GAIND London WIN IAF

\section{Psychiatry and its stigma}

\section{DeAr Sirs}

Regarding Dr G. E. Vincenti's letter, (Bulletin, September 1986, 10, 249), based on my 44 years experience in seven different countries, may I suggest we review our trade name? I do not think that psychiatry or psychiatrist will ever be rehabilitated. Would not it be better to introduce more widely 'psychosomatic medicine' and 'psychophysician', just the same as 'neuro-physicians'? After all, is there any doubt that we are physicians and that we should be more so?

William Osler Hall

IMRE ZADOR

6 Wellington Street

Woollahra, NSW Australia

\section{ECT in the Netherlands and Britain}

\section{Dear Sirs}

Dr Kraemer's suggestion (Bulletin, October 1986, 10, 280-281) that comparison between the Netherlands and Britain in the use of convulsive therapy could be used to examine the prevalence of manic-depression and psychoses for which ECT is used in the two countries. I would suggest that it could also be used to measure standards of treatment.

The only times I have ever seen extreme symptoms of agitation: running backwards and forwards, wringing of the hands, continuous moaning and pulling at the face and hair, was in two mental hospitals which did not use ECT.

Max Hamlton

Emeritus Professor of Psychiatry

University of Leeds

\title{
History of Psychiatry
}

At a meeting of the College at Robinson College, Cambridge on Friday 12 September, it was decided to seek permission from Council to found a Group for the Study of the History of Psychiatry.

The following officers were proposed: Chairman: Dr
Henry R. Rollin; Secretary: Dr German Berrios; Members of Committee: Professor Sydney Brandon, Professor Rachel Rosser, Dr J. Jones, Dr David Healy and Dr William Parry-Jones. 